\title{
Gender and achievement in English language arts, science and mathematics in secondary schools in Nigeria
}

\author{
James S. Etim¹, Alice S. Etim², George Heilman³, S. Mathiyalakan, \& Eno Ntukidem ${ }^{5}$ \\ ${ }^{1}$ Professor of Education, Department of Education, Winston Salem State University, Winston Salem, NC, USA \\ ${ }^{2}$ Assistant Professor of Management Information Systems, Winston Salem State University, Winston Salem, NC. USA \\ ${ }^{3}$ Professor of Management Information Systems, Winston Salem State University, Winston Salem, NC. USA \\ ${ }^{4}$ Professor of Management Information Systems, Winston Salem State University, Winston Salem, NC. USA \\ ${ }^{5}$ Professor of Education, University of Calabar, Nigeria. \\ For correspondence: etimj@wssu.edu
}

\begin{abstract}
The education of girls and women in the areas of Science, Technology, Engineering and Mathematics (STEM) has long been thought of as very crucial for national development. This study investigated whether gender differences might occur in scores attained by Nigerian students on standard subject matter examinations for English Language, Mathematics and Biology in year 2 of Junior Secondary School and Year 2 of Senior Secondary School. Purposive sampling was used to select seven secondary schools in South-South Nigeria. Of the seven schools, four were private and three were public government secondary schools. Scores for 570 students, who were all the students who took the examinations during the 2003-2014 year formed the data for this study. To assess if gender differences exist in students' examination performances, mean examination scores and standard deviations for males and females were calculated separately within each of the three content areas, as well as means and standard deviations for each gender by school level (Junior Secondary School or Senior Secondary School ) within the content areas. Female students performed significantly higher than male students in English Language. At the junior level, female Mathematics scores are only marginally significantly better; while at the senior level, male scores are somewhat (but not significantly) better than female scores. At the junior secondary level female scores in Biology were significantly higher but at the senior secondary school level, the difference was not statistically significant Based on these findings, recommendations were made to ensure the performance of both sexes.
\end{abstract}

Keywords: achievement, empowerment of women, gender differences, junior secondary school, Millennium Goals, senior secondary school, STEM areas

\section{Introduction}

The Nigerian education system is organized around a 9 -3-4 system- nine years of basic education including the Junior Secondary School (JSS), three years of the Senior Secondary School (SS) and 4 years of university education. At the secondary school level, both the junior secondary and the senior secondary school (JSS and SSS) are owned and operated by the Federal Government (Federal Government Colleges -FGC), by State Governments (SG) or private individuals/ church schools (PCS) The first nine years of basic education is divided into six years of primary (elementary) education and three years of the junior secondary school (JSS1-3). According to Obioma (nd) the core curriculum at JSS1-3 includes the following-

1. English Studies

2. Nigerian Language (Hausa/Igbo/Yoruba)

3. Mathematics

4. Basic Science

5. Social Studies

6. Creative and Cultural Arts 
7. The religions (ChristianReligious Knowledge/Islamic ReligiousKnowledge)

8. Physical \& Health Education

9. French Language

10. Basic Technology

11. Civic Education

12. Computer studies/ICT

At the senior secondary schools, there are five compulsory cross cutting areas to be taken by all students- English Language, General Mathematics, one trade with Entrepreneurship Studies, Computer Studies/ICT and Civic Education. There are also courses in the Business Studies area, the Technology area, the humanities area and the Science and mathematics area. Students are expected to take not more than nine and not less than eight courses/ subjects (NERDC 2008), preparatory to writing the national examination (NECO ) or international examination (the West African School Certificate Examination).

The education of girls and women in the areas of Science, Technology, Engineering and Mathematics (STEM) has long been thought of as very crucial for national development. (International Federation of University Women, 2015) According to Hill, Corbett and Rose (2010), "expanding and developing the STEM workforce is a critical issue of government, industry leaders and educators". They pointed out that although there has been tremendous gains of girls and women in the area of education in the last fifty years, " progress has been uneven, and certain scientific and engineering disciplines remain overwhelmingly male" (p.2). Woodall (2015) writing about women in the STEM areas in the USA declared-

Careers in science, technology, engineering, mathematics (STEM) have been growing three times as fast as jobs in other fields. They are predicted to increase an additional $26 \%$ by $2020 \ldots$ Women make up nearly half of this country's workforce yet hold less than a quarter of STEM jobs...Women make up just $23 \%$ of computer programmers and $5 \%$ of mechanical engineers... Women in STEM earn an average $33 \%$ more than women in other fields. (p74).

In a 2015 analysis, the International Federation of University Women indicated that "only $12 \%$ of the global engineering force is women ... and, only $30 \%$ of all science researchers in the world are women". In providing the summary of research on the economics of women in STEM fields, Beede, Julian, Langdon, McKittrick, Khan and Dorris (2011) indicated the following-

- Women with STEM jobs earned 33 percent more than comparable women in non-STEM jobs considerably higher than the STEM premium for men. As a result, the gender wage gap is smaller in STEM jobs than in non-STEM jobs.

- Women hold a disproportionately low share of STEM undergraduate degrees, particularly in engineering.

- Women with a STEM degree are less likely than their male counterparts to work in a STEM occupation; they are more likely to work in education or healthcare.

- There are many possible factors contributing to the discrepancy of women and men in STEM jobs, including: a lack of female role models, gender stereotyping, and less family-friendly flexibility in the STEM fields. Regardless of the causes, the findings of this report provide evidence of a need to encourage and support women in STEM.

\section{Women in STEM in Africa}

Writing about women and STEM in Africa, Agu (2013) pointed to the poor position of women in these fields. She added-

a. Female education in the STEM fields is suffering due to poverty and cultural perceptions that women should be married off early

b. STEM fields are male dominated 
c. Educating girls has positive implications for a country's GDP

In Nigeria, Agwu, Edema and Williams (2014/2015) indicated that "women are severely underrepresented in Science, Technology, Engineering and Mathematics (STEM) related fields - less than $1 \%$ of the doctorate degree holders in these fields" are women. They also indicated that similar statistics was applicable in the higher echelons of policy making bodies.

\section{Gender and Achievement in STEM Areas}

Worldwide, many studies have been carried out on women and the STEM areas especially in the areas of achievement and attitudes. Results have been mixed. Some studies have shown that at the secondary level, male students often perform better in the science and mathematics areas while girls perform better in the language arts( Fennema, 1974; Hanna, 1989; Hanna, 1986). Hanna (1986), in a study of mathematics performance in Ontario pointed out that the "mean percent of correct responses for two of the five topics- geometry and measurement- was slightly higher for boys than girls. These differences ... were statistically significant" (p. 235). In another study ongender and achievement in mathematics, Lindberg, Hyde, Petersen and Linn (2011) pointed out that research "showed that gender differences in mathematics performance were very small and, depending on the sample and outcome measure, sometimes favored boys and sometimes favored girls." (p.1124). In a meta- analysis of studies on gender and science achievement, Becker (1989) concluded that "males showed significant advantages in studies of biology, general science, and physics, but significant differences were not found for studies of mixed science content, and geology and earth sciences, or in a single study of chemistry" .. One explanation for the differences between male and female achievement in mathematics is "gender difference in brain lateralization" (Fennema and Leder, 1990). It should however be pointed out that there are recent studies that show there is no difference in achievement based on gender in mathematics (Bronholt, Goodnow and Conney, 1994) while other studies have shown female students having significantly higher scores in mathematics than boys at the high school level ( Galbraith, 1986; Stockard and Wood, 1984).

\section{Nigerian studies on gender and achievement insome STEM areas}

Lee and Lockheed (1990) found there was no statistical significant difference in achievement based on gender in mathematics. They reported-

There is no significant difference between the mathematics scores of Nigerian adolescent girls and boys, once the other variables in the model (including type of school attended) are taken into account. Similarly, there is no relationship between mathematics achievement and the sex of the mathematics teacher. In addition, neither student motivation, stereotypic attitudes about mathematics, nor teacher experience appear to influence mathematics achievement. (p. 225)

In a more recent study, Ajai and Imoko( 2015) reported that in the area of mathematics, " there is not much difference between the achievement scores of male and female students." (p. 48)

Ogunleye (2001) reported underachievement and under enrolment by girls in the area of sciecne. Olasehinde and Olatoye (2014) reported that there was no significant difference between male and female students in science achievement in public and private schools from a sample of secondary school students in Katsina State. However, they also indicated thatdespite the 'no significant difference' revealed, female students slightly performed better than the male students in public schools.( p.206)

Nigerian studies on gender and achievement in English Language Arts. 
There have been very few studies in the area of English Language Arts. Olanipekun and Zaku (2013) using a sample of students from a college of education in Kwara State reported that male students performed better than female students. They also advised for more studies to be done in the area.

\section{Variables that may affect achievement}

\section{Teachers}

Asimeng-Boahene (2006) indicated that generally, teachers do not encourage girls during mathematics and science classes and that science and mathematics is still a male preserve. "Many teachers, including women teachers, despite much lip service to the equality of girls and boys, just do not believe that girls have the ability to study mathematics and science. The result is that teachers have low expectations of girls' ability to perform well in science and mathematics" (p.716)

In an extensive research report on girls learning in schools across cultures, Postles, Moore, Reilly and Naylor (2013) cited several studies that showed a link between female teachers and higher test scores for girls (p.6). They pointed out that the presence of female teachers helps to create a more "girlfriendly" and supportive learning environment for female students and that is why the higher test scores occured. However, as a cautionary note, they concluded that

...it should also not be assumed that just because a teacher is a woman, she is able or even willing to create an environment that is more conducive to learning for girls or that she will automatically provide extra support for girls (UNESCO 2006). Conversely, it is not the case that male teachers are unable to also effectively encourage and support girls' learning. Indeed, it is imperative that through training and accountability mechanisms all teachers male and female - are supported and encouraged to provide all learners, irrespective of age, ethnicity, caste, religion or learning ability, with an inclusive and supportive child-friendly learning environment that caters to all needs. (pp 7-8)

According to Imhanlahimi and Eloebhose (2006), since the gender, attitude and teaching approach of teachers negatively influence the attitude of female students towards science and technology, teachers need to do the following-

- Teachers should re-examine their teaching approaches

- Science teachers should encourage a high degree of interaction between boys and girls in science and technology classes

- Teachers should avoid criticisms that affect girls' self- image or their capabilities in the science and technology areas ( p.585)

\section{Attitudes and Performance}

To a large extent, student achievement may be influenced by positive attitudes towards oneself and the subject (Deboer, 1987 ; Ajzen and Fishbein1975). Kanafiah and Jumadi(2013) wrote-

Student performance in certain subjects depends on their attitudes towards the subject. Positive attitudes towards the subject will encourage a person to learn the subject much better....A positive attitude can motivate students' critical thinking, being active in the classroom, working together in groups, improve interaction and communication skills (p.133)

Ismail and Anwang (2009) found that students who had a high positive attitude towards mathematics also achieved high in mathematics and science. In the same vein, Mubeen, Saeed and Arif (2013) pointed out that some "studies have reported that there are gender differences in attitude towards mathematics with girls showing more negative attitudes than boys". (p.39). They add that in the study of attitudes, research can be carried out in the following areas- 

a. Attitudes towards subject studied
b. Students perceptions of the role of lecturers in their learning
c. Students' perceptions about their own role in learning. (p.38)

\section{Purpose of the study}

This study investigated whether gender differences might occur in scores attained by Nigerian students on standard subject matter examinations for English Language. Mathematics and Biology in year 2 of Junior Secondary School and Year 2 of Senior Secondary School. The analysis examined gender difference by subject and by grade level across subjects. Specifically, the study investigated the following-

a. Do male students perform significantly better than female students in English Language at the end of year 2 of Junior Secondary School (JSS) and Year 2 of Senior Secondary School (SSS)?

b. Do male students perform significantly better than female students in Mathematics at the end of year 2 of Junior Secondary School (JSS) and Year 2 of Senior Secondary School (SSS)?

c. Do male students perform significantly better than female students in Biology at the end of year 2 of Junior Secondary School (JSS) and Year 2 of Senior Secondary School (SSS)?

As noted in the Introduction section, all students are required to take English Language and Mathematics. At the Junior Secondary School, students take Integrated Science as a required subject area. However, at the Senior Secondary School, even though Biology is not required, the tendency is that it is a subject most likely to be taken by students to meet the science requirement.

\section{Method of Investigation}

Purposive sampling was used to select seven secondary schools in South-South Nigeria, Of the seven schools, four were private and three were public government secondary schools. Also, five of these schools were coeducational, and one was an all male and one also was anall female school. A listing of final scores received by students on standard exams in three content areas were collected from theseseven Nigerian schools. Scores for 570 students, who were all the students who took the examsduring the 2003-2014 year formed the data for this study. Table 1 presents a summary of school demographics, (JSS is junior secondary school and SSS is Senior Secondary School)

TABLE 1: School Demographic Information

\begin{tabular}{|c|c|c|c|cc|cc|c|}
\hline School & Type & Level & Ownership & \multicolumn{2}{|c|}{$\begin{array}{c}\text { Male } \\
\text { Students }\end{array}$} & \multicolumn{2}{c|}{$\begin{array}{c}\text { Female } \\
\text { Students }\end{array}$} & $\begin{array}{c}\text { Total } \\
\text { Students }\end{array}$ \\
\hline 1 & Coed & JSS 2 & Private & 22 & $(43 \%)$ & 29 & $(57 \%)$ & 51 \\
\hline 2 & Coed & JSS 2 & Private & 37 & $(50 \%)$ & 37 & $(50 \%)$ & 74 \\
\hline 3 & Female & SSS 2 & Public & 0 & $(0 \%)$ & 91 & $(100 \%)$ & 91 \\
\hline 4 & Male & JSS 2 & Private & 122 & $(100 \%)$ & 0 & $(0 \%)$ & 122 \\
\hline 5 & Coed & SSS 2 & Public & 22 & $(52 \%)$ & 20 & $(48 \%)$ & 42 \\
\hline 6 & Coed & JSS 2 & Public & 62 & $(44 \%)$ & 78 & $(56 \%)$ & 140 \\
\hline 7 & Coed & SSS 2 & Private & 16 & $(32 \%)$ & 34 & $(68 \%)$ & 50 \\
\hline Total & & & & \multicolumn{2}{|c|}{281} & \multicolumn{2}{|c|}{289} & 570 \\
\hline
\end{tabular}

The subjects tested were English, Mathematics and Biology. Some of the students completed all three exams while some completed only one or two of the exams. Table 2 presents a summary of students who completed tests by content area.

TABLE 2: Number of Student Exams by Content Area

\begin{tabular}{|l|c|c|c|c|c|c|}
\hline School & English & & Math & Biology & Total \\
\hline
\end{tabular}




\begin{tabular}{|c|c|c|c|c|c|c|c|}
\hline & M & $\mathrm{F}$ & M & $\mathrm{F}$ & M & $\mathrm{F}$ & Students \\
\hline 1 & 22 & 29 & 22 & 29 & 22 & 29 & 51 \\
\hline 2 & 36 & 37 & 37 & 37 & 36 & 37 & 74 \\
\hline 3 & 0 & 91 & 0 & 91 & 0 & 62 & 91 \\
\hline 4 & 0 & 0 & 121 & 0 & 0 & 0 & 122 \\
\hline 5 & 22 & 20 & 22 & 20 & 22 & 20 & 42 \\
\hline 6 & 62 & 78 & 62 & 78 & 62 & 77 & 140 \\
\hline 7 & 16 & 34 & 0 & 0 & 16 & 34 & 50 \\
\hline Gender Total & 158 & 289 & 264 & 255 & 158 & 259 & \\
\hline Content Total & \multicolumn{2}{|c|}{447} & \multicolumn{2}{|c|}{519} & \multicolumn{2}{|c|}{417} & 570 \\
\hline
\end{tabular}

The maximum score on each exam is 100 points. To assess if gender differences exist in students' examination performances, mean examination scores and standard deviations for males and females were calculated separately within each of the three content areas, as well as means and standard deviations for each gender by school level (Junior Secondary School or Senior Secondary School ) within the content areas. T-tests were then performed to check for significant differences in mean examination scores across genders.

\section{Results}

\section{For English Exams}

As Table 2 indicates, 447 students completed the English examination. The overall exam means and standard deviations (SD) for the English examination by gender are presented in Table 3. The means and standard deviation by gender for each grade level is also presented. Significant differences in mean scores are noted.

TABLE 3: Gender Differences in Engilish Exam Scores

\begin{tabular}{|l|c|c|c|}
\hline Overall & Male & Female & $\begin{array}{c}\text { Sig. Diff. } \\
\text { Male/Female }\end{array}$ \\
\hline For juniors & $\begin{array}{c}\mathrm{N}=158 \\
\text { Mean }=51.63 \\
(\mathrm{SD}=17.58)\end{array}$ & $\begin{array}{c}\mathrm{N}=289 \\
\text { Mean }=57.80 \\
(\mathrm{SD}=14.22)\end{array}$ & $\mathrm{p}=.000$ \\
\hline For seniors & $\begin{array}{c}\mathrm{N}=120 \\
\mathrm{Mean}=50.58 \\
(\mathrm{SD}=18.26)\end{array}$ & $\begin{array}{c}\mathrm{N}=144 \\
\text { Mean }=56.86 \\
(\mathrm{SD}=16.06)\end{array}$ & $\mathrm{p}=.004$ \\
\hline $\begin{array}{l}\mathrm{N}=38 \\
\text { Sig. Diff. at Junior Secondary School /Senior }\end{array}$ & $\begin{array}{c}\mathrm{N}=145 \\
\text { Mean }=58.74 \\
(\mathrm{SD}=12.11)\end{array}$ & $\mathrm{NS}$ \\
\hline
\end{tabular}

Overall, female English exam scores are significantly higher than males. The difference in scores is especially noticeable at the junior level. By the time the students get to the senior level, females are still scoring nearly 4 percentage points higher than males, but the difference is no longer statistically significant. Scores for both genders improve when going from the junior to senior level, males more so than females; but the improvement in scores is not statistically significant. 
519 students completed the Math exam (see Table 2). The overall exam means and standard deviations (SD) for the Math exam by gender are presented in Table 4. The means and standard deviation by gender for each grade level is also presented. Significant differences in mean scores are noted.

TABLE 4: Gender Differences in Math Exam Scores

\begin{tabular}{|c|c|c|c|}
\hline Overall & Male & Female & $\begin{array}{c}\text { Sig. Diff. } \\
\text { Male/Female }\end{array}$ \\
\hline For juniors & $\begin{array}{c}\mathrm{N}=264 \\
\text { Mean }=41.40 \\
(\mathrm{SD}=16.31)\end{array}$ & $\begin{array}{c}\mathrm{N}=255 \\
\text { Mean }=50.12 \\
(\mathrm{SD}=17.71)\end{array}$ & $\mathrm{p}=.000$ \\
\hline $\begin{array}{c}\mathrm{N}=242 \\
\mathrm{Nean}=39.45 \\
(\mathrm{SD}=15.21)\end{array}$ & $\begin{array}{c}\mathrm{N}=144 \\
\text { Mean }=\mathbf{4 2 . 3 2} \\
(\mathrm{SD}=15.89)\end{array}$ & $\mathrm{p}=.078$ \\
\hline For seniors & $\begin{array}{c}\mathrm{N}=22 \\
\mathrm{Mean}=\mathbf{6 2 . 8 6} \\
(\mathrm{SD}=12.25)\end{array}$ & $\begin{array}{c}\mathrm{N}=111 \\
(\mathrm{SD}=14.59)\end{array}$ & $\mathrm{NS}$ \\
\hline Sig. Diff. Junior/Senior & $\mathrm{P}=.000$ & $\mathrm{P}=.000$ & \\
\hline
\end{tabular}

Overall, female Mathematics examination scores are significantly higher than males. At the junior level, female Mathematics scores are only marginally significantly better; while at the senior level, male scores are somewhat (but not significantly) better than female scores. Even though males have better scores at the senior level, the number of males completing the Math exam is so small relative to the number of females that it does not significantly affect the overall score.. Scores for both genders improve significantly when going from the junior to senior level. The increase in male scores is about 5 points better than for females.

\section{For Biology Examination}

417 students completed the Biology examination (see Table 2). The overall exam means and standard deviations (SD) for the Math exam by gender are presented in Table 4. The means and standard deviation by gender for each grade level is also presented. Significant differences in mean scores are noted.

TABLE 4: Gender Differences in Biology Scores

\begin{tabular}{|c|c|c|c|}
\hline \multirow{2}{*}{ Overall } & Male & Female & $\begin{array}{c}\text { Sig. Diff. } \\
\text { Male/Female }\end{array}$ \\
\hline For juniors & $\begin{array}{c}\mathrm{N}=158 \\
\text { Mean }=51.18 \\
(\mathrm{SD}=15.52)\end{array}$ & $\begin{array}{c}\mathrm{N}=259 \\
\text { Mean }=55.95 \\
(\mathrm{SD}=14.16)\end{array}$ & $\mathrm{p}=.001$ \\
\hline $\begin{array}{c}\mathrm{N}=120 \\
\mathrm{Mean}=48.39 \\
(\mathrm{SD}=15.60)\end{array}$ & $\begin{array}{c}\mathrm{N}=143 \\
\text { Mean }=51.41 \\
(\mathrm{SD}=13.70)\end{array}$ & $\mathrm{p}=.096$ \\
\hline For seniors & $\begin{array}{c}\mathrm{N}=38 \\
\mathrm{Mean}=59.97 \\
(\mathrm{SD}=11.62)\end{array}$ & $\begin{array}{c}\mathrm{N}=116 \\
(\mathrm{SD}=12.69)\end{array}$ & $\mathrm{NS}$ \\
\hline Sig. Diff. Junior/Senior & $\mathrm{p}=.000$ & $\mathrm{p}=.000$ & \\
\hline
\end{tabular}

Overall, female Biology exam scores are significantly better than males, with females having higher mean scores at both the junior and senior levels. The 3 point difference in scores is at the junior level is marginally significant, while the $1 \frac{1 / 2}{2}$ point difference at the senior level is not. Scores for both 
genders improve significantly when going from the junior to senior level, with males improving about $1 \frac{1 / 2}{2}$ points more than females.

\section{Discussion}

At junior secondaryschool 2 (equivalent to $7^{\text {th }}$ grade in USA system), female students score significantly higher than male students in English Language. At senior secondary school2 (equivalent to 11 th grade in the USA system), female students continue to score higher than male students in English Language but the scores are not statistically significant. This study is in disagreement with Fakeye (2010) who reported that at the senior secondary level, male students performed significantly higher than female students in English Language and Abdu-Raheem (2012) who reported that there was no significant difference in English Language achievement at the end of senior secondary school in Nigeria.

In the area of Mathematics, female students scored higher than male students at junior secondary school year 2 while male students scored higher than female students in senior secondary school year 2. However, at none of the levels was the score statistically significant. This study is in line with the findings of Ajai and Imoko (2015) who reported no significant difference in male and female achievement in mathematics.

At the junior secondary level female scores in Biology were significantly higher but at the senior secondary school level, the difference was not statistically significant. There are no reported known studies in terms of gender and achievement in Biology at the junior secondary school level but at the senior secondary school level, the study agrees with findings from Olasehinde and Olatoye (2014b) who reported no significant difference between male and female students in achievement in biology.

\section{Conclusion}

United Nations Millennium Goal 3 calls for the promotion of gender equality and the empowerment of women. Specifically, this Goal advocates for the elimination of gender disparity in primary and secondary education, preferably by 2005 and in all levels of education by 2015. An important goal worldwide for many countries is not only the increase of girls and women in STEM fields but also their achievement in these fields. Many studies are showing some improvement in female achievement in the areas of science and mathematics at the pre-university level. This study sheds some light on the situation in south- south Nigeria. Schools systems in Nigeria should continue to design strategies to not only encourage girls and women in science and mathematics education but also ensure their continued success. Female students continue to score significantly higher than male students in English Language. Strategies should be developed to ensure that boys do better in this subject area given the importance of English language for communication and in the workplace in Nigeria.

\section{Acknowledgement}

This research was funded by a small Professional Development Committee Grant $(\$ 4,200.00)$ awarded to Professor James S. Etim during the 2014-2015 school year that enabled the travel to and collection of data in Nigeria. Special thanks go also to Professor EnoNtukidem of University of Calabar, Nigeria who facilitated the process.

\section{References}

Abdu-Raheem, B. O. (2012) The Influence of Gender on Secondary School Students' Academic Performance in South-West, Nigeria. Journal of Social Science. 31(1), 93-98

Agu, E (2013) Female Education in STEM Fields for African Girls. http://waawfoundation.org/2012/08/13/female-education-instem-fields-for-african-girls/ Retrieved July 21, 2014.

Agwu, N., Edema, M \& Williams, S. (2014/2015). Culture and Women Stories: A Framework or Capacity Building in Science, 
Tecnology, Engineering and Mathematics (STEM) Related Fields. Mathematics Teaching Research Journal online 7.2. http://www.hostos.cuny.edu/MTRJ/archives/volume7/issue2/Culture\%20and\%20Womens\%20Stories.pdf Retrieved July 20, 2015.

Ajai, J.T. \&Imoko, I.I. (2015). Gender differences in mathematics achievement and retention scores: A case of problem-based learning method. International Journal of Research in Education and Science . 1 (1), 45- 50.

Asimeng-Boahene, L (2006) Gender Inequity in Science and Mathematics Education in Africa: The Causes, Consequences and Solutions. Education, 126 (4), 711-728.

Ajzen, I and Fishbein, M (1975) Understanding attitude and predicting social behavior. New Jersey: Prentice Hall

Becker, B (1989). Gender and science achievement: a reanalysis of studies from two meta-analyses. Journal of Research in Science Teaching. 26 (2), 141-169

Beede, D., Julian, T., Langdon, D., McKittrick, G., Khan, B., \&Doms, M. (2011). Women in STEM: A Gender Gap to Innovation. Washington DC: U.S. Department of Commerce, Economics and Statistics Administration. Issue Brief \#04-11

Bronholt, L.J., Goodnow, J. \&Conney, G. H. (1994). Influences of gender stereotypes on adolescents' perceptions of their won achievement. American Educational Research Journal. 31, 675-692.

Cavanagh, C (2005 May 4) Educators Revisit Girls' Loss of Science/Interest. Education Week. May 4, p 24, 34, Deboer, G.E (1987) Predicting continued participation in College Chemistry for men and women. Journal of Research in Science Teaching 24 (6), 53

Eccles, J.S. (1987) Gender roles and women's' achievement-related choices. Psychology of Women Quarterly 11, 135-172

Fakeye, D.O. (2010). Students' Personal Variables as Correlates of Academic Achievement in English as a Second Language in Nigeria. Journal of Social Science 22 (3), 205-211

Fennema, E (1974). Mathematics learning and the sexes: A review. Journal of Research in Mathematics Education. 5 , 126-139.

Fennema , E \&Leder, G ed. (1990). Mathematics and gender: Influences of teachers and students. New York: Teachers College Press.

Galbraith, P.L. (1986). The use of mathematical strategies: Factors and features affecting performance. Educational Studies in Mathematics, 17: 413-441.

Hanna, G (1986) Sex Differences in the Mathematics Achievement of Eight Graders in Ontario. Journal of Research in Mathematics Education 17.3: 231-237.

Hanna, G. (1989). Mathematics achievement of girls and boys in grade eight: Results from twenty countries. Educational Studies in Mathematics. 20 (2) 225-232

Hill, C.H. , Corbett, C ,. Rose, A . (2010). Why So Few: Women in Science, Technology, Engineering and Mathematics. Washington D.C.: American Association for University Women

Igbo, J.N., Onu, V.C. \&Obiyo, N.O. (2015) Impact of Gender Stereotype on Secondary School Students Self-Concept and Achievement. Sage Open JournalsDOI: 10.1177/2158244015573934

Imhanlahimi, E.O., Eloebhose, F.E. (2006) Problems and Prospects of Women access to Science and technology Education in Nigeria College Student Journal. 40 (3), 583-587

International Federation of University Women (2015, January). Policy Update 01/15. http://www.ifuw.org/wpcontent/uploads/2015/01/IFUW-PolicyUpdate-0115v2-STEM.pdf Retrieved June 12, 2015.

Ismail, N.A and Anwang, H. (2009). Differences in mathematics achievement among eight grade students in Malaysia. Journal International Education Studies 2, 8-11.

Kanafiah, S \&Jumadi, A (2013). Students' Perception Towards Mathematics: Attitudes, Interests and Lecturers' Teaching. International Symposium on Mathematical Sciences and Computing Research. 6-7 th December 2013. Perak, Malaysia. http://www.academia.edu/6836597/Students_Perception_Towards_Mathematics_Attitudes_Interest_And_Lecturers_Te aching Retrieved April 3, 2015

Lee, V. E. \& Lockheed, ME. (1990) The Effects of Single-Sex Schooling on Achievement and Attitudes in Nigeria Comparative Education Review, 34( 2 ), 209-231

Lindberg, S.S., Hyde, J.S., Petersen, J.L \& Linn, M.C. (2010). New Trends in Gender and Mathematics Performance: A MetaAnalysis. Psychological Bulletin. 136 (6), 1123-1135.

Mubeen, S., Saeed, S., Arif, M.H. (2013) Attitude towards Matheamtics and Academic Achievement in Mathematics among secondary level Boys and Girls.IOSR Journal ofHumanities and Social Sciences. 6 (4), 38-41.

National Science Foundation. (2000). Shaping the future. Washington D.C : National Science Foundation.

NERDC (2008) The new senior secondary school curriculum structure at a glance. Abuja, Federal Ministry of Education.

Obioma, G (nd). The 9-Year Basic Education Curriculum (Structure, Contents, and Strategy for Implementation): Nigeria's Experience in Educational Reform.

http://live.v1.udesa.edu.ar/files/EscEdu/Inclusi\%C3\%B3n\%20Educativa/39\%20Godswill\%20Obioma\%20(Nigeria).pdf Retrieved May 10, 2012

Ogunleye, A.O (2001). . Girls' Perceptions of Strategies for improving Low enrolment, underachievement and attitudes of Girls in Physics at the Senior Secondary School level. Journal of the Science Teachers Association of Nigeria, 36 (1), $61-71$

Olanipekun, S.S. \&Zaku, JA. (2013) Gender analysis of students' entry qualification in English language in colleges of education in Kwara State. International Journal of Secondary Education 1.5: 23-25.

Olasehinde, K.J \&Olatoye, R.A. (2014) A Comparative Study of Public and Private Senior Secondary School Students' Science Achievement in Katsina State, Nigeria. Journal of Educational and Social Research. 4(3), 203-207 Doi:10.5901/jesr.2014.v4n3p203

Olasehinde, K.J \&Olatoye, R.A. (2014b) Comparison of Male and Female Senior Secondary School Students' Learning Outcomes in Science in Katsina State, Nigeria. Mediterranean Journal of Social Sciences. 5(2), 517-523. 
Postles, C., Moore, K., Reilly, A and Naylor, R. (2013). Girls learning: investigating classroom practices that promote girls' learning. London, UK: Plan UK. http://www.plan-uk.org/resources/documents/260260 Retrieved April 4, 2015

Stockard, J. \& Wood, J.W. (1984). The myth of female underachievement: a re-examination of sex differences in academic underachievement. American Educational Research Journal. 21, 825-838.

UNESCO (2012) From Access to Equality: Empowering Girls and Women Through Literacy and Secondary Education. Paris, France: UNESCO.

UNESCO. World Declaration of Education for All

http://www.unesco.org/education/efa/ed_for_all/background/jomtien_declaration.shtml Retrieved June 12, 2007

UNESCO (2006). The impact of women teachers on girls' education, Bangkok: UNESCO: US Agency for International Development (2008) Education from a Gender Equality Perspective.. Washington DC: USAID Office of Women in Development/Equate Project.

Woodall, A (2015). Some surprising news about women, math, science-jobs. More. p.74 